\title{
The Development and Validation of Questionnaire on Autism Spectrum Disorders and its Association With Plastic-Based Food Contact Materials
}

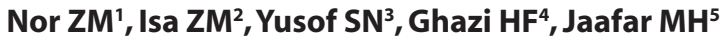

\section{Abstract}

Introduction: Autism is a neuropsychiatric disorder. Multiple factors have been identified as causes of autism spectrum disorder. Many studies indicated genetic as the main risk factor, but environmental risk factors are also seen as contributing factors. Exposure to environmental pollutants such as endocrine disrupting chemicals (EDCs) can occur as early as in the mother's womb. The main concern of EDCs in food packaging are Bisphenol A (BPA) and phthalates. The objectives of this study are to develop and validate a questionnaire for the assessment of habitual usage of plasticbased food contact materials (FCM) as a proxy for exposure to this group of EDCs.

Material and Methods: The questionnaire developed by organising a focus group discussion among experts. An interview-guided pilot study was then done to 250 respondents for construct validation process. In the validation process, test-retest study for reliability, Cronbach alpha for internal consistency, exploratory factor analysis and confirmatory factor analysis were done.

Results: The questionnaire achieved kappa value ranged between 0.800 to 0.900 for knowledge, 0.610 to 0.815 for perception and 0.607 to 1.000 for self-care product section. Cronbach alpha value ranged between 0.600 to 0.780 .

Conclusions: Exploratory and confirmatory factor analysis approved the final model for phase one consisting of four domains with total of 13 items and final model for phase two consists of three domains with total of nine items.

Key words: autism spectrum disorder; bisphenol A; phthalates; questionnaire development

\section{Introduction}

T he autism spectrum disorder (ASD) is a range of conditions

classified as neuro developmental disorders that have an onset since infancy. Its clinical presentation is characterised by impairment in reciprocal social interaction, communication with others and by a preference for repetitive, stereotyped behaviours.

Based on the recent report by the Autism and Developmental Disabilities Monitoring (ADDM) Network, the overall ASD prevalence
${ }^{1}$ Zaleha Md Nor, Rembau District Health Office, Rembau, Negeri Sembilan, Malaysia; ${ }^{2}$ Zaleha Md Isa, Department of Community Health, Faculty of Medicine, Universiti Kebangsaan Malaysia, Kuala Lumpur,Malaysia; ${ }^{3}$ Siti Norbayah Yusof, National Cancer Institute, Wilayah Persekutuan Putrajaya, Malaysia; ${ }^{4}$ Hasanain Faisal Ghazi, Public Health Medicine Specialist, Community Medicine Unit, International Medical School, Management and Science University (IMU), Malaysia; ${ }^{5}$ Mohd Hasni Jaafar, Department of Community Health, Faculty of Medicine, Universiti Kebangsaan Malaysia, Kuala Lumpur,Malaysia

\author{
Address for correspondence \\ Zaleha Md Nor, \\ Rembau District Health Office, \\ 71300 Rembau, \\ Negeri Sembilan, \\ Malaysia \\ E-mail: zalehamdnor@yahoo.com.my
}

\section{Acknowledgements: None \\ Funding: Nil \\ Conflict of Interest: None \\ Permission from IRB: Yes}

How to cite

Nor ZM, Isa ZM, Yusof SN, Ghazi HF, Jaafar $\mathrm{MH}$. The Development and Validation of Questionnaire on Autism Spectrum Disorders and its Association with Plastic-Based Food Contact Materials. J Nepal Paediatr Soc 2018;38(3):182-9.

doi: http://dx.doi.org/10.3126/jnps.v38i3.20671

Submitted on: 2018-08-04

Accepted on: 2020-02-08

This work is licensed under a Creative Commons Attribution 3.0 License. 
estimate of 16.8 per 1,000 children (one in 56 children) aged eight years in 2014. Prevalence of ASD reaching nearly $3 \%$ in some communities and representing an increase of $150 \%$ since $2000 .^{1}$

Autism is a neuropsychiatric disorder. Multiple factors have been identified as causes of autism spectrum disorder, however the cascade of the disease is still not clearly defined. ${ }^{2}$ One of the main factors of this condition was genetic as identified by Folstein and Rutter in $1977^{3}$ in their twin study and the gene region involved was reported as $15 q 11-13$ by Nurmi et al. in 2003. ${ }^{4}$ In a systematic review done by Rossignol ${ }^{5}$ regarding factors associated with ASD, he identified four main factors contributing which are: immune dysregulation or inflammation, oxidative stress, mitochondrial dysfunction and environmental toxicant exposures.

Food (and beverages) contact materials (FCM) are all materials and articles intended to come into contact with food, such as packaging and containers, kitchen equipment, cutlery and dishes. ${ }^{6}$ Different materials are used to pack foodstuffs such as plastics, paper, cardboard, metals, glass, regenerated cellulose, ceramics, rubbers and elastomers, waxes, wood, cork, and textiles. Most metal cans have polymeric coatings, and paper or carton packaging often is coated or laminated with plastic as the effective food contact material, essentially making plastics the main food contact material in today's packaging landscape. ${ }^{7}$

Chemicals leaching into food will increase human exposure, and cause long-term impact on health. Even at low concentrations, chronic exposure to endocrine disrupting chemicals (EDC) is toxicologically relevant. Concerns increase when humans are exposed to mixtures of similar acting EDCs and/or during sensitive windows of development. ${ }^{8}$ The most concerned EDCs in food packaging are BPA and phthalates. Exposure estimates based on food, air, dusts, consumer product concentrations and intake rates indicate that diet is likely to be a major source of exposure to BPA and DEHP [di(2-ethylhexyl)phthalate]. ${ }^{9,10}$ BPA and phthalate exposures were substantially reduced when diets were restricted to food with limited packaging. ${ }^{11}$

The objectives of this study are to develop and validate a questionnaire for the assessment of habitual usage of plastic-based FCM as a proxy for exposure to this group of EDCs.

\section{Material And Methods}

The questionnaire is developed by organising a focus group discussion $(n=5)$. Later, the questionnaire was face validated by a small group of respondents which includes experts from their respective fields $(n=10)$. They are specialists in Public Health, Toxicology, Family Medicine, Paediatric, Nutrition, English and Malay language expertise. An interview guided pilot study was done among 250 respondents for reliability and validation proses. Sample size of 250 was used based on five respondents per item for structural equation modelling using analysis for a moment structures. ${ }^{12}$ Mothers with children aged between two to 10 years old was selected as respondent.

Data was analysed with IBM Statistical Package for Services Solutions (SPSS) version 23.0 and IBM SPSS AMOS (analysis for a moment structures) version 23.0 for reliability and construct validity. Ethical approval obtained from The National University of Malaysia research ethics committee.

\section{Results}

Questionnaire development:

The questionnaire consisted of six sections $(A-F)$. The data was collected via interview guided questionnaire and pictures were used to facilitate respondent's understanding.

a. Section A is related to sociodemographic, socioeconomic data and personal information.

b. Section B is related to the ante-natal history, birth history, vaccination history and admission history of the child.

c. Section $C$ is related to the history of the mother during pregnancy and a year after birth.

d. Section $D$ is assessing the exposure of occupation and house environment to the subject during the antenatal and infancy periods.

e. Section $E$ is about knowledge and perception of the mother regarding environmental toxicants (BPA and Phthalates).

f. Section $F$ is related to the exposure of BPA and Phthalates by the practice of using plastic-based food contact materials. It is divided into 2 phases which are the mother's exposure during antenatal period and the child exposure during infancy. In this section, scoring are according to frequency in which the choices of 'Never'; '1-3 times every 6 months'; '1-3 times a month'; 'Once a week'; '2-4 times a week'; 'Once every day'; 'Everytime', are used.

Questionnaire was developed based on literature review. Table 1 shows the concept, items and sources of the questionnaires. 


\section{Questionnaire validation:}

After discussions with the experts in face validation process, some question items were dropped as they were confusing or repeating or had significant answers. The likert scale was also changed from 7 likert scales to 5 likert scales because the scales used initially was misleading and overlapping.

A pilot study was conducted at a government agency involving the staff and users of the facility among mothers with two to 10 years old children. A total of 250 respondents had answered the questionnaires. Before the pilot study, random 30 respondents were selected to complete the test-retest study. Respondents were required to complete the set of questions and repeat them again after 1-2 weeks.

In the knowledge section (Table 2), all 9 questions showed almost perfect agreement that range between 0.800 to 0.900 . In perception section (Table 3 ), six out of eight questions have a kappa value which indicates substantial agreement value from 0.610 to 0.815 . Two of the questions in the perception section scored 0.557 and 0.604 which is moderate agreement. For the practice section (Table 4), from 46 questions in Phase one, six questions have moderate agreement and 40 questions have almost perfect agreement. In phase 2 (Table 5), out of 18 questions, eight have moderate agreement while 10 questions showed strong and almost perfect agreement. For self-care product section, the kappa value ranged from 0.607 to 1.000 except for talcum usage which scored 0.464 .

Table 6 shows the cronbach alpha value for each part. During the analysis, items that have Corrected Item-Total Correlation values of 0.3 to 0.7 are included. The cronbach alpha value obtained is from 0.600 to 0.780. After the analysis, the number of items also changed. In perception section, two items (B1c code question and B1d code) were removed because they had a low Corrected Item-Total Correlation value. In the practice section for phase one, the items decreased from 18 items to 13 items and for phase two, the items decreased from 14 items to nine items.

For construct validity, two analyses have been conducted, Exploratory Factor Analysis (EFA) and Confirmatory Factor Analysis (CFA).

Exploratory Factor Analysis conducted for the practice in the usage of plastic based food contact materials has two parts, Phase one and Phase two in view of the difference in the method of exposure and time of exposure. In initial model, during phase one, the questions were divided into eight domains with 45 items. While for Phase two, the questions were divided into two domains and the number of items is 18 items. A model has been generated after the exploratory factor analysis.

Table 1: Concept, items and source in development of questionnaires

\begin{tabular}{|c|c|c|}
\hline Concept & Items & Source \\
\hline \multirow[b]{3}{*}{ Knowledge } & i. Plastic Safety Indication- 4 items & Food Standards Agency 201513 \\
\hline & ii. Plastic resin identification number- 1 item & Plastics Industry Trade Association 14 \\
\hline & $\begin{array}{l}\text { iii. International and national action on Bisphenol A/ } \\
\text { Phthalates- } 4 \text { items }\end{array}$ & $\begin{array}{l}\text { Malaysia Food Act } 1983 \text { Section } 34 \text { (g) } \\
\text { 15; European Parliament 2005, } 2007 \\
\text { 16,17; United States Congress } 200818\end{array}$ \\
\hline \multirow{2}{*}{ Perception } & i. Plastic usage in contact with food and beverages- 4 items & \multirow{2}{*}{$\begin{array}{l}\text { Nam et al. } 2010 \text { 19; Welshons et al. } \\
200620\end{array}$} \\
\hline & ii. Toxic materials in plastic based container- 2 items & \\
\hline \multirow{9}{*}{ Practice } & i. Eating self-cooked food- 1 item & \multirow{4}{*}{$\begin{array}{l}\text { Rudel et al. 201111; Carwile et al. } \\
201121\end{array}$} \\
\hline & ii. Buying the groceries -2 items & \\
\hline & iii. Organic foods -1 item & \\
\hline & iv. Eating outside food - 4 items & \\
\hline & v. Utensils for cooking, serving and storing food -6 items & Rudel et al. 201111 \\
\hline & vi. Policarbonate container usage -2 items & Carwile et al. 200921 \\
\hline & vii. Packed/tinned food/beverages - 15 items & $\begin{array}{l}\text { Welshons et al. } 2006 \text { 20; Cao et al. } 2010 \\
\text { 22, } 201123\end{array}$ \\
\hline & $\begin{array}{l}\text { viii. Packed/tinned food/beverages usage in various } \\
\text { conditions- } 7 \text { items }\end{array}$ & $\begin{array}{l}\text { Amiridou \& Voutsa } 2011 \text { 24; Le et al. } \\
2008 \text { 25; Cao \& Corriveau } 2008 \text { 26; Nam } \\
\text { et al. } 2010 \text { 19; Welshons et al. } 200620\end{array}$ \\
\hline & ix. Feeding bottle usage & $\begin{array}{l}\text { Nam et al. } 2010 \text { 19; Biedermann-Brem } \\
\text { et al. } 200827 .\end{array}$ \\
\hline
\end{tabular}


Table 2: Kappa value in test-retest for knowledge section $(n=30)$

\begin{tabular}{lc}
\hline Item & Kappa \\
\hline 1. Safe for food and beverage symbol (B2i) & 0.900 \\
\hline 2. Microwave safe symbol (B2ii) & 0.900 \\
\hline 3. Freezer safe symbol (B2iii) & 0.833 \\
\hline 4. Dishwasher safe symbol (B2iv) & 0.800 \\
\hline $\begin{array}{l}\text { 5. Resin identification number (B3) } \\
\text { 6. Ban on selling polycarbonate feeding } \\
\text { bottle containing Bisphenol A by }\end{array}$ & 0.867 \\
$\begin{array}{l}\text { Malaysian government (B4) } \\
\text { 7. Ban on usage of Bisphenol A or } \\
\begin{array}{l}\text { Phthalate ester in manufacturing of food } \\
\text { containers and packages. (B5) }\end{array}\end{array}$ & 0.833 \\
\hline $\begin{array}{l}\text { 8. Know regarding Bisphenol A free } \\
\text { products. (B6) }\end{array}$ & 0.833 \\
\hline $\begin{array}{l}\text { 9. Know regarding Phthalates free } \\
\text { products. (B7) }\end{array}$ & 0.867 \\
\hline
\end{tabular}

Table 3: Kappa value in test-retest for perception section $(n=30)$

\begin{tabular}{ll}
\hline \multicolumn{1}{c}{ Item } & Kappa \\
\hline $\begin{array}{l}\text { 1. All plastic containers can be used for food } \\
\text { and beverage (B1a) }\end{array}$ & 0.613 \\
\hline $\begin{array}{l}\text { 2. All plastic containers can be used for hot } \\
\text { food and beverages (B1b) }\end{array}$ & 0.610 \\
\hline $\begin{array}{l}\text { 3. Reused plastic container is still in good } \\
\text { condition (B1c) }\end{array}$ & 0.624 \\
\hline $\begin{array}{l}\text { 4. Change baby feeding bottle every } 6 \\
\text { months (B1d) }\end{array}$ & 0.557 \\
\hline $\begin{array}{l}\text { 5. Improper use of food packaging/ } \\
\text { container can leach chemicals into foods } \\
\text { (B1e) }\end{array}$ & 0.815 \\
\hline $\begin{array}{l}\text { 6. Chemicals leached from food packaging / } \\
\text { container may harm your body (B1f) }\end{array}$ & 0.691 \\
\hline 7. How often do you choose Bisphenol A \\
$\begin{array}{l}\text { (BPA)-free products for your plastics use. } \\
\text { (C18) }\end{array}$ & 0.604 \\
\hline 8. Is it easy for you to get BPA free products \\
\begin{tabular}{l} 
(C20) \\
\hline
\end{tabular}
\end{tabular}

Table 4: Kappa value in test-retest for practice section in phase $1(n=30)$

\begin{tabular}{llc}
\hline \multicolumn{1}{c}{ Item } & Kappa \\
\hline 1. Home cooking (C1) & 0.735 \\
\hline 2. & Pre-packed raw materials (C2i) & 0.793 \\
\hline 3. & Loose raw materials (C2ii) & 0.629 \\
\hline 4. & Organic raw materials (C2iii) & 0.650 \\
\hline $\begin{array}{l}\text { 5. Using non plastic utensils during meal } \\
\text { preparation (C3i) }\end{array}$ & 0.709 \\
\hline $\begin{array}{l}\text { 6. Using plastic utensils during meal } \\
\text { preparation (C3ii) }\end{array}$ & 0.654 \\
\hline $\begin{array}{l}\text { Using plastic container for storing food } \\
\text { (C4i) }\end{array}$ & 0.604
\end{tabular}

Item Kappa

8. Using non plastic container for storing food (C4ii)

0.783

9. Using plastic kitchenware for serving food (C5i)

0.522

10. Using non plastic kitchenware for serving $\quad 0.683$ food (C5ii)

11. Using personal plastic drinking bottle (C6) 0.771

12. Drink from a large quantity polycarbonate dispenser (C7)

0.813

13. Eat out or pack outside food (C8)

0.819

14. Eating fast food (C9)

0.762

15. Choosing packed food (C10i) $\quad 0.600$

16. Choose to dine in with freshly cooked $\quad 0.696$ meals (C10ii)

17. Re-use plastic containers (C11) 0.536

18. Heating food in plastic containers (C12) $\quad 0.773$

19. Using plastic containers to serve food or drinks that are still hot (C13)

20. Consume packaged water /food that was left in the hot sun (C14)

21. Frequency of taking canned food/ packed food: Fish (C16i)

22. Frequency of taking canned food/ packed food: Meat (C16ii)

23. Frequency of taking canned food/ packed food: Corn (C16iii)

24. Frequency of taking canned food/ packed food: Tomato sauce (C16iv)

25. Frequency of taking canned food/ packed food: Soup (C16v)

0.623

0.688

0.855

0.647

0.694

0.443

26. Frequency of taking canned food/ packed food: Vegetables (C16vi)

27. Frequency of taking canned food/ packed food: Green Beans (C16vii)

28. Frequency of taking canned food/ packed food: Baked Beans (C16viii)

29. Frequency of taking canned food/ packed food: Condensed milk (C16ix)

30. Frequency of taking canned food/ packed food: Evaporated milk (C16x)

31. Frequency of taking canned food/ packed food: Milk powder (C16xi)

32. Frequency of taking canned food/ packed food: Snacks (C16xii)

33. Frequency of taking canned food/ packed food: Ice cream (C16xii)

34. Frequency of taking canned food/ packed 0.820 food: Chocolate (C16xiii)

35. Frequency of taking canned food/ packed food: Chewing gum (C16xiv)

36. Frequency of taking canned food/ packed food: Canned drinks (C16xv)

0.597

0.688

0.838

0.739

0.821

0.609

0.636

0.770

0.679

0.720

37. Taking food / beverages from damaged / dented can (C17) 
Table 5: Kappa value in test-retest for practice section in phase $2(n=30)$

\begin{tabular}{|c|c|}
\hline Item & Kарра \\
\hline 1. Using plastic feeding bottle (C23) & 0.587 \\
\hline 2. Using glass feeding bottle (C24) & 1.000 \\
\hline $\begin{array}{l}\text { 3. Using very hot water during preparation } \\
\text { of milk in the feeding bottle }(\mathrm{C} 25)\end{array}$ & 0.661 \\
\hline $\begin{array}{l}\text { 4. Using warm water during preparation of } \\
\text { milk in the feeding bottle (C26) }\end{array}$ & 0.773 \\
\hline $\begin{array}{l}\text { 5. Washing feeding bottle with detergents } \\
\text { (C27) }\end{array}$ & 0.605 \\
\hline $\begin{array}{l}\text { 6. Boil/ steam/ immerse feeding bottle in } \\
\text { hot water before usage }(\mathrm{C} 28)\end{array}$ & 0.541 \\
\hline $\begin{array}{l}\text { 7. Choose BPA-free products for feeding } \\
\text { bottles (C29) }\end{array}$ & 0.712 \\
\hline $\begin{array}{l}\text { 8. Using plastic kitchenware to serve food } \\
\text { for child (C30) }\end{array}$ & 0.488 \\
\hline $\begin{array}{l}\text { 9. Use glass kitchenware to serve food to } \\
\text { your child (C31) }\end{array}$ & 0.675 \\
\hline $\begin{array}{l}\text { 10. Use plastic container to serve food that } \\
\text { is still hot for child (C32) }\end{array}$ & 0.551 \\
\hline $\begin{array}{l}\text { 11. Use plastic container to store food for } \\
\text { child (C33) }\end{array}$ & 0.515 \\
\hline $\begin{array}{l}\text { 12. Use glass container to store food for } \\
\text { child (C34) }\end{array}$ & 0.653 \\
\hline 13. Child playing with plastic toys (C35) & 0.478 \\
\hline $\begin{array}{l}\text { 14. Child placed plastic toys in his/her } \\
\text { mouth (C36) }\end{array}$ & 0.482 \\
\hline
\end{tabular}

Table 6: Cronbach alpha value for each section

\begin{tabular}{cccc}
\hline \multirow{2}{*}{ Section } & \multicolumn{2}{c}{ No of item } & \multirow{2}{*}{$\begin{array}{c}\text { Cronbach } \\
\text { Alpha }\end{array}$} \\
\cline { 2 - 3 } & Initial & Final & \\
\hline Knowledge & 9 & 9 & 0.78 \\
\hline Perception & 6 & 4 & 0.66 \\
\hline Practice (Phase 1) & 18 & 13 & 0.70 \\
\hline Practice (Phase 2) & 14 & 9 & 0.60 \\
\hline Self care products & 13 & 13 & 0.72 \\
\hline
\end{tabular}

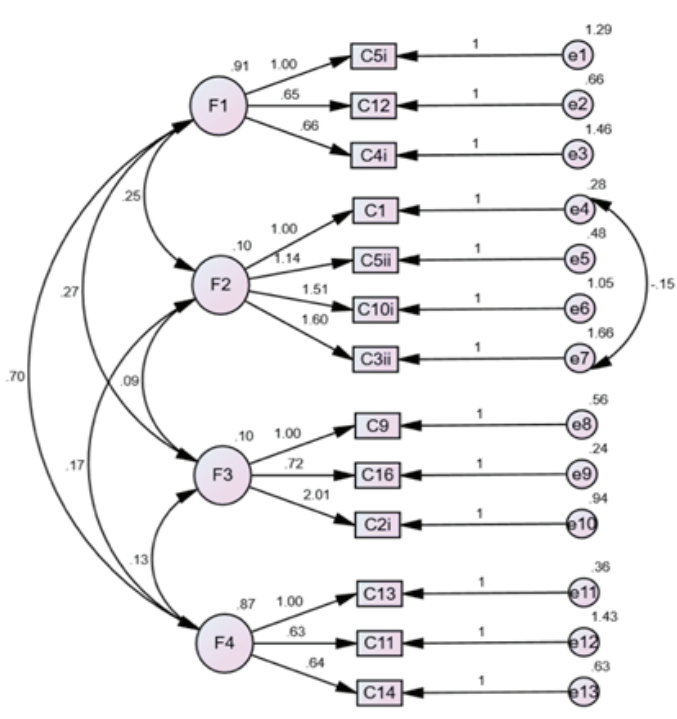

Fig. 1: The model for practice in usage of plastic based food contact materials by mothers during pregnancy (phase 1)
Table 7: Loading factor for practice in usage of plasticbased food contact materials by mothers during pregnancy (phase 1)

\begin{tabular}{|c|c|c|c|c|}
\hline \multirow{2}{*}{ Item } & \multicolumn{4}{|c|}{ Domain } \\
\hline & 1 & 2 & 3 & 4 \\
\hline Using plastic & & & & \\
\hline $\begin{array}{l}\text { kitchenware for } \\
\text { serving food (C5i) }\end{array}$ & 0.678 & & & \\
\hline $\begin{array}{l}\text { Heating food in plastic } \\
\text { containers }(C 12)\end{array}$ & 0.666 & & & \\
\hline $\begin{array}{l}\text { Using plastic } \\
\text { container for storing } \\
\text { food }(\mathrm{C} 4 \mathrm{i})\end{array}$ & 0.414 & 0.369 & & \\
\hline Home cooking $(\mathrm{C} 1)$ & & 0.765 & & \\
\hline Using non plastic & & & & \\
\hline $\begin{array}{l}\text { kitchenware for } \\
\text { serving food (C5ii) }\end{array}$ & & 0.658 & & \\
\hline $\begin{array}{l}\text { Choosing packed } \\
\text { food }(\mathrm{C} 10 \mathrm{i})\end{array}$ & & 0.494 & & \\
\hline $\begin{array}{l}\text { Using plastic } \\
\text { utensils during meal } \\
\text { preparation (C3ii) }\end{array}$ & 0.374 & 0.459 & & \\
\hline Eating fast food (C9) & & & 0.803 & \\
\hline $\begin{array}{l}\text { Frequency of taking } \\
\text { canned food/ packed } \\
\text { food (C16) }\end{array}$ & & & 0.780 & \\
\hline $\begin{array}{l}\text { Pre-packed raw } \\
\text { materials }(\mathrm{C} 2 \mathrm{i})\end{array}$ & 0.588 & & 0.342 & 0.335 \\
\hline $\begin{array}{l}\text { Using plastic } \\
\text { containers to serve } \\
\text { food or drinks that are } \\
\text { still hot (C13) }\end{array}$ & 0.502 & & & 0.444 \\
\hline $\begin{array}{l}\text { Re-use plastic } \\
\text { containers (C11) }\end{array}$ & & & & 0.736 \\
\hline $\begin{array}{l}\text { Consume packaged } \\
\text { water /food that was } \\
\text { left in the hot sun } \\
\text { (C14) }\end{array}$ & & & & 0.674 \\
\hline
\end{tabular}

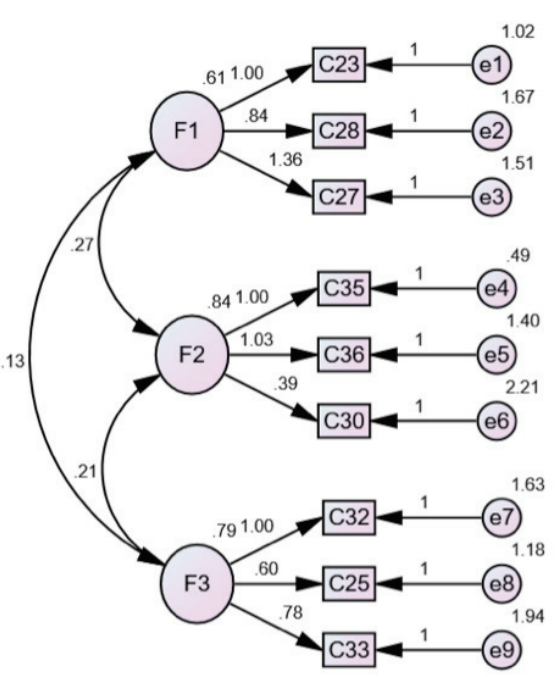

Fig. 2: Model for practice in usage of plastic-based food contact materials after birth up to 1 year old (phase 2) 
Table 8: Loading factor for practice in usage of plastic based food contact materials after birth up to one year old (phase 2)

\begin{tabular}{|c|c|c|c|}
\hline \multirow{2}{*}{ Item } & \multicolumn{3}{|c|}{ Domain } \\
\hline & 1 & 2 & 3 \\
\hline $\begin{array}{l}\text { Using plastic feeding bottle } \\
\text { (C23) }\end{array}$ & 0.789 & & \\
\hline $\begin{array}{l}\text { Boil/ steam/ immerse feeding } \\
\text { bottle in hot water before } \\
\text { usage (C28) }\end{array}$ & 0.726 & & \\
\hline $\begin{array}{l}\text { Washing feeding bottle with } \\
\text { detergents (C27) }\end{array}$ & 0.632 & & \\
\hline $\begin{array}{l}\text { Child playing with plastic toys } \\
\text { (C35) }\end{array}$ & & 0.778 & \\
\hline $\begin{array}{l}\text { Child place plastic toys in his/ } \\
\text { her mouth }(\mathrm{C} 36)\end{array}$ & & 0.811 & \\
\hline $\begin{array}{l}\text { Using plastic kitchenware to } \\
\text { serve food for child (C30) }\end{array}$ & & 0.479 & \\
\hline $\begin{array}{l}\text { Use plastic container to serve } \\
\text { food that is still hot for child } \\
\text { (C32) }\end{array}$ & & & 0.763 \\
\hline $\begin{array}{l}\text { Using very hot water during } \\
\text { preparation of milk in the } \\
\text { feeding bottle (C25) }\end{array}$ & & & 0.695 \\
\hline $\begin{array}{l}\text { Use plastic container to store } \\
\text { food for child (C33) }\end{array}$ & & & 0.654 \\
\hline
\end{tabular}

Table 7 is the loading factor obtained after running the exploration analysis in phase 1 . This model is found to comply with confirmatory factor analysis conducted subsequently. The conditions for the exploratory factor analysis have also been met, in which the evaluation for adequacy of sampling is

satisfactory (Kaiser-Meyer-Olkin $\mathrm{KMO}=0.745$ ) and the value of Bartlett's Test of Sphericity shows that there is a relationship pattern between the items $(x 2=$ 483.925, df $=78, p<0.001)$. All items have diagonal elements in the Anti-Correlation Matrix of above 0.5 $(0.659 \text { to } 0.808)^{28}$.

This model describes 53.6 percent of the total variance in the pilot study data. Domain 1 consists of three items with an Eigen value of 2.999 which represents 23.072 percent variance in the data. Domain 2 consists of four items with Eigen value $=1.765$ and this represents $13.579 \%$ variance. Domain 3 consists of 3 items with Eigen value $=1.189$ representing $9.144 \%$ variance in the data. Whereas, domain 4 consists of 3 items with Eigen value $=1.015$ and represents $7.808 \%$ variance in data.

Figure 1 is the model obtained for practice section in phase 1 after the exploratory factor analysis was conducted. Initially the model was analysed using the Maximum Likelihood Estimation (MLE) method. Using this MLE method, it is necessary to fulfil the assumption of Multivariate Normality (MVN) where this assumption is fulfilled if the critical ratio (cr) for multivariable kurtosis is $<5$. The model has been found to have $\mathrm{cr}=11.179$. Therefore the model does not satisfy the assumption for multivariate normality. Since assumptions for multivariate normality are not met, the Asymptotically Distribution-Free method was used.29 The value of CMIN/DF = $2.067(<3)$, Goodness of Fit Index GFI = 0.946 (> 0.90), Approximation Goodness of Fit Index AGFI $=0.916$ (> 0.90), Tucker-Lewis Index TLI = 0.759 (>0.90), Comparative Fit Index CFI = 0.821 (>0.90), Root Mean Squared Error of Approximation RMSEA $=0.065(<0.08)$. Bootstrap method has also been implemented for cross validation of the model that has been generated. The Bollen-stein Bootstrap test on this model gives a value of $p=0.274$; in which the test did not reject the null hypothesis and the model is considered correct.

Table 9 shows the loading factor of the practice of using plastic-based food contact materials after birth and up to one year old (Phase two). The conditions for the factor exploration analysis have also been met, in the assessment of the adequacy of the sampling is satisfactory (Kaiser-Meyer-Olkin KMO $=0.623$ ) and the Bartlett's Test of Sphericity value indicates there is relationship pattern between the data and that the data is appropriate for the factor exploration analysis ( $x^{2}=$ 274.153, $d f=36, p<0.001$ ). All items have diagonal elements in the Anti-Correlation Matrix above 0.5 , that is between 0.523 up to $0.815 .^{28}$

This model describes 54.981 percent of the total variance in this preliminary study. For domain 1 , it consists of three items of questions and has an Eigen value of 2.187 which represents 24.299 percent variance in the data. Domain two consists of three items with Eigen value $=1.532$ and this represents $17.027 \%$ variance. Meanwhile, domain three consists of three items with Eigen value $=1.229$ representing $13.655 \%$ variance in data.

Figure 2 is the model obtained after the confirmatory factor analysis is conducted for the practice in usage of plastic-based food contact materials after birth up to one year old (phase two). The model is analysed using the Maximum Likelihood Estimation (MLE) method. This model meets the assumption of Multivariate Normality (MVN) where it is fulfilled if the critical ratio (cr) for multivariable kurtosis is $<5^{30}$ and from this model, the critical ratio obtained was 4.372 . In this way, the value of CMIN/DF = $1.627(<3)$, Goodness of Fit Index GFI $=0.967(>0.90)$, Approximation Goodness of Fit Index AGFI $=0.938$ (> 0.90), Tucker-Lewis Index TLI = 0.897 
(>0.90), Comparative Fit Index CFI = $0.931 \quad$ (>0.90), Root Mean Squared Error of Approximation RMSEA = $0.050(<0.08)$ was found. Therefore this model is fit to be used.

After both exploratory and confirmatory factor analysis were carried out, the final model for phase one consists of four domains with 13 items compared to the initial model that consist of eight domains and 18 items. The final model for phase two consists of three domains with nine items compared to two domains and 14 items initially.

\section{Discussion}

During validation process, there are several items of questions that are considered important in the assessment of exposure to the plastic-based food contact materials were left out from the final model. Due to the importance of the questions and after discussions among researchers, the important questions were grouped and analysed separately as another factor. According to all indicator points in the validation process, these questionnaires have gone through a systematic process, therefore they are valid and reliable to be used in studying the exposures of bisphenol $A$ and phthalates ester from plastic based food contact materials.

Diet is the main route for bisphenol $A$ and phthalate esters (endocrine disruptor chemicals) to enter the human body. Bisphenol $\mathrm{A}$ and phthalate esters are widely used in the manufacturing of plastics and plastic-based food contact materials are the main source of these endocrine disruption chemicals. This questionnaire assesses the exposure to plastic-based food contact materials as reported by respondents. There were no comparisons between the results of this questionnaire with the level of bisphenol $A$ and phthalate esters in human body due to unavailability of accredited laboratory during this study.

However, the questionnaire is able to provide an estimate of exposure, in which it assessed the exposure based on the habitual use of plastic-based food contact materials for each individual. This questionnaire shows a long-term exposure to plastic-based food contact materials for each individual because human habits are difficult to change. In contrary, by using laboratory methods, the concentration of bisphenol A and phthalate esters will be analysed using their metabolites in urine samples. It indicates short-term exposure because of the short lifetime of bisphenol $A$ and phthalate esters in human body.

The questionnaire can be improved in the future by comparing it with concentrations of bisphenol $A$ and phthalate esters in the human body. This is to ensure the questionnaire is good in estimating the exposure of the chemicals.

\section{Conclusion}

Based on the results of validation, this questionnaire can be used to assess the exposure of bisphenol $A$ and phthalate esters in plastic-based food contact materials. However, it can be improved if the questionnaire is validated with a laboratory method.

\section{References}

1. Centre for Disease Control. Prevalence of autism spectrum disorder among children aged 8 yearsAutism and Developmental Disabilities Monitoring Network, 11 Sites, United States, 2010. Morbidity and Mortality Weekly Report 63(2): 1-21.

2. Szatmari P. The causes of autism spectrum disorders. Br Med J. 2003;326:173-4. DOI: https://doi. org/10.1136/bmj.326.7382.173

3. Folstein S, Rutter M. Infantile Autism: A Genetic Study of 21 Twin Pairs. J Child Psychol and Psychiatry. 1977; 18297-321.

4. Nurmi EL, Dowd M, Tadevosyan-Leyfer O, Haines JL, Folstein SE, Sutcliffe JS. Exploratory subsetting of autism families based on savant skills improves evidence of genetic linkage to 15q11-q13. J Am Acad Child Adolesc Psychiatry. 2003;42:856-63. DOI: 10.1097/01.CHI.0000046868.56865.0F
5. Rossignol DA, Frye RE. A review of research trends in physiological abnormalities in autism spectrum disorders: immune dysregulation, inflammation, oxidative stress, mitochondrial dysfunction and environmental toxicant exposures. Mol Psychiatry. 2012;17:389-401. DOI: 10.1038/mp.2011.165

6. European Food Safety Authority (EFSA): Food Contact Materials 2015. Available form http://www.efsa.europa. eu/en/topics/topic/foodcontactmaterials

7. Castle L. Chemical migration into food: an overview. Chemical migration and food contact materials. Cambridge: CRC Press/Woodhead Publishing Limited; 2007.

8. Muncke J. Exposure to endocrine disrupting compounds via the food chain: Is packaging a relevant source? Sci Total Environ. 2009;407:4549-59. DOI: 10.1016/j.scitotenv.2009.05.006

9. National Toxicology Program. NTP-CERHR monograph on the potential human reproductive and developmental effects of di (2-ethylhexyl) 
phthalate (DEHP). NTP CERHR MON v, vii-7, II-iii-xiii passim. 2006.

10. National Toxicology Program, U.S. Department of Health and Human Services NTP-CERHR Monograph on the Potential Human Reproductive and Developmental Effects of Bisphenol A. 2008.

11. Rudel, RA, Gray JM, Engel CL, Rawsthorne TW, Dodson RE, Ackerman JM, et al. Food packaging and bisphenol $A$ and bis(2-ethyhexyl) phthalate exposure: findings from a dietary intervention. Environ Health Perspect 2011;119:914-20. DOI: 10.1289/ ehp. 1003170

12. Benter PM, Chou CP. Practical issues in structural modeling. Sociol Methods Res. 1987;16(1), 78-117. DOI: https://doi.org/10.1177/0049124187016001004

13. Food Standards Agency. Determination of Phthalates in Foods and Establishing Methodology to Distinguish their Source; Food and Environment Research Agency: Yorkshire, UK, 2012. Available form https:// www.food.gov.uk/sites/default/files/media/document/ phthalates-report.pdf

14. The Plastics Industry Trade Association, SPI Resin Identification Code - Guide to Correct Use. Available from http://www.plasticsindustry.org/AboutPlastics.

15. Malaysia. Food Regulations 1985: Arrangement of Regulations 2014. Available from http://fsq.moh.gov. $\mathrm{my} / \mathrm{v} 6 / \mathrm{xs} / \mathrm{dl}$.php?filename=730b5042d10be434b44c3 165d1ec588b.pdf

16. EC (European Commission). Directive 2005/84/ EC of the European Parliament and of the Council of 14 December 2005. amending for the 22nd time Council Directive 76/769/ EEC on the approximation of the laws, regulations and administrative provisions of the Member States relating to restrictions on the marketing and use of certain dangerous substances and preparations (phthalates in toys and childcare articles). Off J Eur Union 2005;L 344(40). Available from https://eur-lex.europa.eu/LexUriServ/LexUriServ. do?uri=OJ:L:2005:344:0040:0043:EN:PDF

17. EC (European Commission). Commission Directive 2007/19/EC of March 30 2007. Amending Directive 2002/72/EC relating to plastic materials and articles intended to come into contact with food and Council Directive 85/572/EEC laying down the list of stimulants to be used for testing migration of constituents of plastic materials and articles intended to come into contact with foodstuffs. Off J Eur Union 2007;L 97(17). Available from https://eur-lex.europa.eu/LexUriServ/ LexUriServ.do?uri=OJ:L:2007:319:0001:0036:EN:P DF

18. United States Congress. Consumer Product Safety Improvement Act of 2008. Public Law No. 110-314
(HR 4040). Available from https://www.congress. gov/110/plaws/publ314/PLAW-110publ314.pdf

19. Nam SH, Seo YM, Kim MG. Bisphenol A migration from polycarbonate baby bottle with repeated use. Chemosphere .2010; 79(9): 949-52. DOI: 10.1016/j. chemosphere.2010.02.049

20. Welshons WV, Nagel SC, Vom Saal FS. Large effects from small exposures. III. Endocrine mechanisms mediating effects of Bisphenol $A$ at levels of human exposure. Endocrinology. 2006;147(6):56-69. DOI: 10.1210/en.2005-1159

21. Carwile JL, Ye X, Zhou X, Calafat AM, Michels KB. Canned food consumption and urinary bisphenol-A: a randomized cross-over trial. JAMA. 2011;306: 221820. DOI: 10.1001/jama.2011.1721

22. Cao XL, Corriveau J, Popovic S. Bisphenol A in canned food products from Canadian markets. J Food Prot. 2010; 73:1085-1089. DOI: 10.4315/0362-028x73.6.1085

23. Cao XL, Perez-Locas C, Dufresne G, Clement G, Popovica S, Beraldin F, et al. Concentrations of bisphenol $A$ in the composite food samples from the 2008 Canadian total diet study in Quebec City and dietary intake estimates. Food Addit Contam. 2011;28:791-8. DOI: 10.1080/19440049.2010.513015

24. Amiridou D, Voutsa D. Alkylphenols and phthalates in bottles water. J Hazard Mater. 2011;185:281-6. DOI: 10.1016/j.jhazmat.2010.09.031

25. Le HH, Carlson EM, Chua JP, Belcher SM. Bisphenol $A$ is released from polycarbonate drinking bottles and mimics the neurotoxic actions of estrogen in developing cerebellar neurons. Toxicology Letters 2008;176(2):149-156. DOI: 10.1016/j. toxlet.2007.11.001

26. Cao XL, Corriveau J. Survey of Bisphenol A in bottled water products in Canada. Food Addit. Contam. 2008;1:161-4. DOI: 10.1080/02652030802563290

27. Biedermann-Brem S, Grob K, Fjeldal P. Release of Bisphenol A from polycarbonate baby bottles: mechanisms of formation and investigation of worst-case scenarios. Eur Food Res Technol. 2008;227:1053-60. DOI: 10.1007/s00217-008-0819-9

28. Yong AG, Pearce S. A Beginner's Guide to Factor Analysis: Focusing on Exploratory Factor Analysis. Tutor Quant Methods Psychol. 2013;9(2):79-94.

29. De Coster J. Overview of Factor Analysis. 1998. Available from http://www.stat-help.com/notes.html

30. Byrne BM. Structural equation modeling with AMOS: Basic concepts, applications, and programming (2nd ed.). Routledge/Taylor \& Francis. 2010. 